\title{
High temperature superconductivity in orthorhombic $\mathrm{LaBa}_{2} \mathrm{Cu}_{3} \mathrm{O}_{7-\delta}$
}

\author{
V KAMARAJ, K KANDASWAMY* and V SRINIVASAN* \\ Department of Physics. PSG Autonomous College of Arts and Science, Coimbatore 641 014, \\ India \\ *Department of Physics, Sri Ramakrishna Mission Vidyalaya Arts College, Coimbatore \\ 641020 , India
}

\begin{abstract}
High temperature superconducting $\mathrm{LaBa}_{2} \mathrm{Cu}_{3} \mathrm{O}_{7-\delta}$ has been prepared by ceramic and nitrate methods to understand the influence of preparation conditions on superconductivity. The characterization was carried out by X-ray diffraction and magnetic susceptibility measurements. $T_{c}$ onset was observed at $88 \mathrm{~K}$. Meissner effect has been observed above the liquid nitrogen temperature.
\end{abstract}

Keywords. High temperature superconductivity; Meissner effect; ceramic method: nitrate method.

\section{Introduction}

Since the discovery of superconductivity around $90 \mathrm{~K}$ (Wu et al 1987) there has been i. emendous interest for preparing materials belonging to $\mathrm{Y}-\mathrm{Ba}-\mathrm{Cu}-\mathrm{O}$ system. The crystal structure of the superconducting phase has been shown to be oxygen-deficient distorted perovskite structure (Cava et al 1987; Rao et al 1987; Nagarajan et al 1987). These newly discovered high $T_{c}$ superconductors have been classified into two groups based on their crystal structure. (i) $\mathrm{La}_{2-x} \mathrm{M}_{x} \mathrm{CuO}_{4}(\mathrm{M}=\mathrm{Ca}, \mathrm{Sr}, \mathrm{Ba})$ with tetragonal $\mathrm{K}_{2} \mathrm{NiF}_{4}$ structure with $0 \cdot 1 \leqslant x \leqslant 0 \cdot 3$ (Kishio et al 1987; Rao et al 1987; Cava et al 1987). Zero resistance $T_{c}$ values in the range $20-48 \mathrm{~K}$ have been observed depending on the metal and its content. (ii) $\mathrm{LaBa}_{2} \mathrm{Cu}_{3} \mathrm{O}_{7}$ with orthorhombic structure distorted, oxygen-deficient perovskite structure exhibiting a $T_{c}$ of $95 \mathrm{~K}$ (Wu et al 1987; Ganguly et al 1987; Cava et al 1987; Sampathkumaran et al 1987; Kishio et al 1987; Murphy et al 1987; Engler et al 1987; Hor et al 1987). The superconducting properties of these two systems are sensitive to oxygen stoichiometry and in both systems, the mixed valence of copper (- $\mathrm{CuO}_{2}$-planes) is responsible for the metallic behaviour and high $T_{c}$ superconductivity. Considerable work has been done by replacing yttrium by other rare earth materials like La, Gd, Dy, Eb etc in many laboratories. As the reported values of $T_{c}$ are different, an attempt has been made in the present study to optimize the superconducting behaviour of $\mathrm{LaBa}_{2} \mathrm{Cu}_{3} \mathrm{O}_{7-\delta}$, by preparing this compound by ceramic and nitrate methods separately and characterizing them by $\mathrm{X}$-ray and magnetic susceptibility measurements.

\section{Experimental}

In the ceramic method, the compound was prepared by solid-state reaction. Powders of $\mathrm{La}_{2} \mathrm{O}_{3}, \mathrm{BaCO}_{3}$ and $\mathrm{CuO}$ were mixed in molar ratio of $0.5: 2: 3$ in agate mortar and pestle and were then calcined at $950^{\circ} \mathrm{C}$ for $10 \mathrm{~h}$ in air followed by grinding and reheating at $970^{\circ} \mathrm{C}$ in flowing oxygen for $10 \mathrm{~h}$. The sample was cooled slowly in a 
stream of oxygen to $400^{\circ} \mathrm{C}$. At $400^{\circ} \mathrm{C}$ the sample was annealed in oxygen for $20 \mathrm{~h}$ and cooled down to room temperature.

In the nitrate method, $\mathrm{La}_{2} \mathrm{O}_{3}, \mathrm{BaCO}_{3}$ and $\mathrm{Cu}\left(\mathrm{NO}_{3}\right)_{2} \cdot 6 \mathrm{H}_{2} \mathrm{O}$ with $0 \cdot 5: 2: 3$ mole ratio was dissolved in $6 \mathrm{~N} \mathrm{HNO}_{3}$. The resultant solution mixture was evaporated to dryness at $100^{\circ} \mathrm{C}$. The nitrate precursor thus obtained was calcined at different temperatures. A minimum temperature of $850^{\circ} \mathrm{C}$ was sufficient for the formation of the 1-2-3 phase. The resultant oxide was again heat-treated at $970^{\circ} \mathrm{C}$ for about $4 \mathrm{~h}$ in $\mathrm{O}_{2}$ to achieve good crystallinity. The nitrate-derived 1-2-3 material on oxygen annealing at $400^{\circ} \mathrm{C}$ for $20 \mathrm{~h}$ was employed to check its superconductivity. Oxygen content of the samples was estimated by reducing a known amount of the 1-2-3 material in flowing $\mathrm{H}_{2}$ gas at $800^{\circ} \mathrm{C}$ to $\mathrm{La}_{2} \mathrm{O}_{3}, \mathrm{BaO}$ and metallic copper. The samples were characterized by $\mathrm{X}$-ray diffraction and magnetic susceptibility measurements.

\section{Results and discussion}

The ceramic method requires repeated heating and grinding schedules in general and also higher calcination temperature for longer durations to form the 1-2-3 phase. The resulting oxide, even after oxygen annealing, remained tetragonal. The peak at $2 \theta=32.3^{\circ}$ in XRD does not show any splitting as it is usually observed in orthorhombic YBC. From the oxygen estimation the composition of the sample was found to be $\mathrm{LaBa}_{2} \mathrm{Cu}_{3} \mathrm{O}_{6.7}$. No Meissner effect was observed above $77 \mathrm{~K}$ for this sample. Several investigators, as in the present case, could not observe any superconductivity above $77 \mathrm{~K}$ for $\mathrm{LaBa}_{2} \mathrm{Cu}_{3} \mathrm{O}_{7-\delta}$ (Subba Rao et al 1987).

Lanthanum-based 1-2-3 compound derived from nitrate method shows broad $\mathrm{X}$-ray reflections. Though heat-treatment at $850^{\circ} \mathrm{C}$ is enough for the formation of 1-2-3 phase, a further increase in temperature is essential to achieve good crystallinity. The nitrate-derived materials show Meissner effect above liquid nitrogen temperature only after high temperature calcination and oxygen annealing. Thus, the nitrate-derived sample on calcination at $970^{\circ} \mathrm{C}$ for $4 \mathrm{~h}$ followed by oxygen annealing

Table 1. Method of preparation and characteristics of $\mathrm{LaBa}_{2} \mathrm{Cu}_{3} \mathrm{O}_{7-\delta}$

\begin{tabular}{|c|c|c|c|c|c|c|c|}
\hline Sample & $\begin{array}{l}\text { Method of } \\
\text { preparation }\end{array}$ & $\begin{array}{l}\text { Starting } \\
\text { reagents }\end{array}$ & Ratio & $\begin{array}{l}\text { Calcination } \\
\text { in air } \\
\text { temperature } \\
\text { and time }\end{array}$ & $\begin{array}{l}\text { Oxygen } \\
\text { annealing }\end{array}$ & $\begin{array}{l}\text { Cell } \\
\text { dimen- } \\
\text { sion }\end{array}$ & $T_{c}$ onset \\
\hline $\mathrm{LaBa}_{2} \mathrm{Cu}_{3} \mathrm{O}_{7-\delta}$ & Nitrate & $\begin{array}{l}\mathrm{La}_{2} \mathrm{O}_{3} \\
\mathrm{BaCO} \\
\mathrm{Cu}\left(\mathrm{NO}_{3}\right)_{2} \cdot 6 \mathrm{H}_{2} \mathrm{O} \\
6 \mathrm{~N} \mathrm{HNO}_{3}\end{array}$ & $0: 5: 2: 3$ & $\begin{array}{l}850^{\circ} \mathrm{C} \\
10 \mathrm{~h}\end{array}$ & $\begin{array}{l}400^{\circ} \mathrm{C} \\
20 \mathrm{~h}\end{array}$ & $\begin{array}{l}a=3.90 \\
b=3.92 \\
c=11.78\end{array}$ & $\begin{array}{l}\text { Not } \\
\text { observed } \\
\text { above } \\
77 \mathrm{~K}\end{array}$ \\
\hline $\mathrm{LaBa}_{2} \mathrm{Cu}_{3} \mathrm{O}_{7-\delta}$ & Nitrate & $\begin{array}{l}\mathrm{La}_{2} \mathrm{O}_{3} \\
\mathrm{BaCO}_{3} \\
\mathrm{Cu}\left(\mathrm{NO}_{3}\right)_{2} \cdot 6 \mathrm{H}_{2} \mathrm{O} \\
6 \mathrm{NHNO}_{3}\end{array}$ & $0 \cdot 5: 2: 3$ & $\begin{array}{l}850 \mathrm{C} \\
10 \mathrm{~h}\end{array}$ & $\begin{array}{l}970^{\circ} \mathrm{C} \\
4 \mathrm{~h} \text { and } \\
400^{\circ} \mathrm{C} \\
20 \mathrm{~h}\end{array}$ & $\begin{array}{l}a=3.90 \\
b=3.92 \\
c=11.78\end{array}$ & $88 \mathrm{~K}$ \\
\hline $\mathrm{LaBa}_{2} \mathrm{Cu}_{3} \mathrm{O}_{7} \delta$ & Ceramic & $\begin{array}{l}\mathrm{La}_{2} \mathrm{O}_{3} \\
\mathrm{BaCO}_{3} \\
\mathrm{CuO}\end{array}$ & $0-5: 2: 3$ & $\begin{array}{l}950^{\circ} \mathrm{C} \\
10 \mathrm{~h}\end{array}$ & $\begin{array}{l}970 \mathrm{C} \\
10 \mathrm{~h}\end{array}$ & - & $\begin{array}{l}\text { Not } \\
\text { observed } \\
\text { above } \\
77 \mathrm{~K}\end{array}$ \\
\hline
\end{tabular}



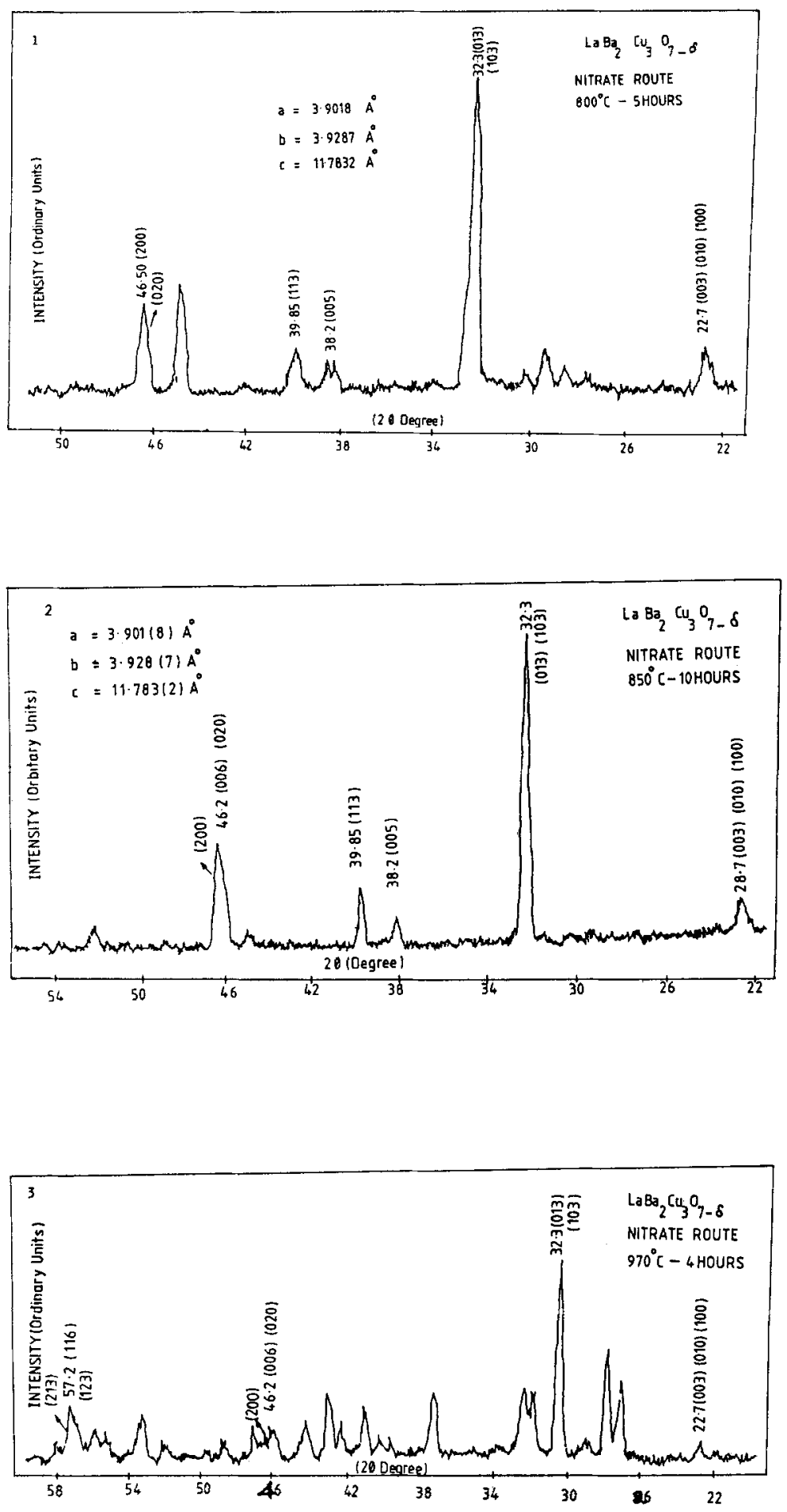

Figures 1-3. X-ray $\left(\mathrm{CuK}_{2}\right)$ diffraction pattern of the $\mathrm{LaBa}_{2} \mathrm{Cu}_{3} \mathrm{O}_{7-s}$ oxide superconductor annealing at $1.800^{\circ} \mathrm{C}$ for $5 \mathrm{~h} .2 .850^{\circ} \mathrm{C}$ for $10 \mathrm{~h} .3 .970^{\circ} \mathrm{C}$ for $4 \mathrm{~h}$. 


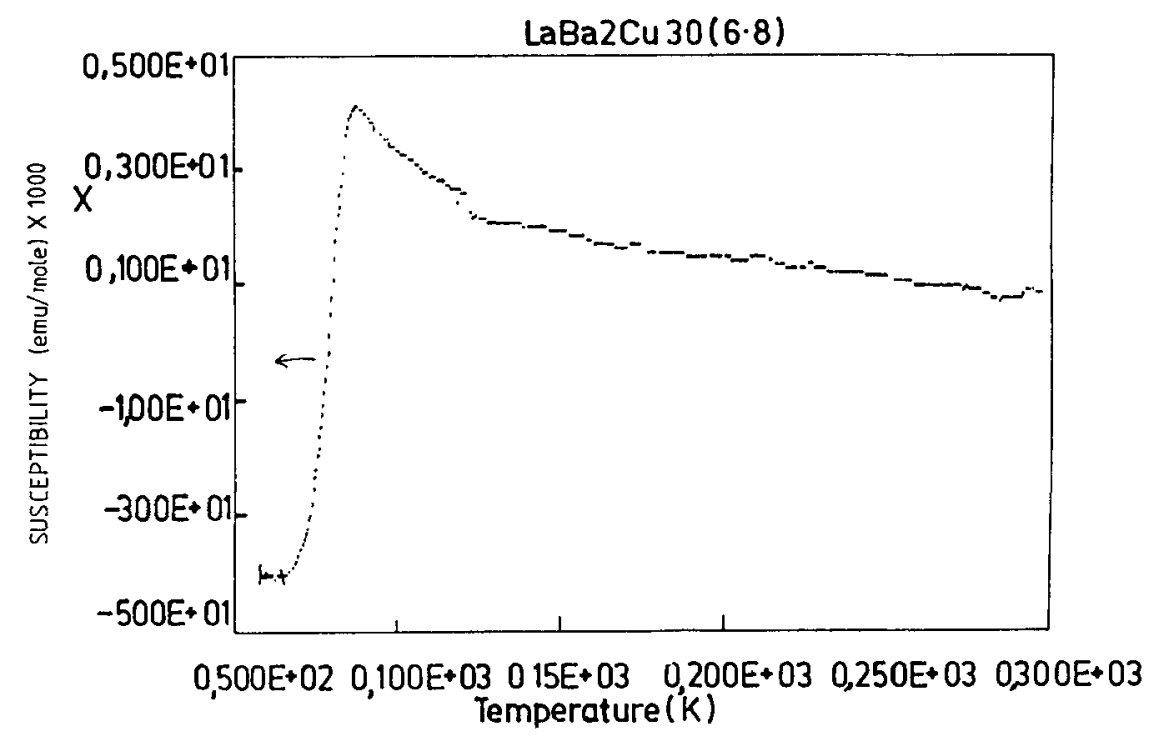

Figure 4. Temperature dependence of the magnetic susceptibility of sample $\mathrm{LaBa}_{2} \mathrm{Cu}_{3} \mathrm{O}_{7-\delta}$.

at $400^{\circ} \mathrm{C}$ for $20 \mathrm{~h}$ showed diamagnetic behaviour with a $T_{c}$ onset at $88 \mathrm{~K}$ (figure 4). The above observation is in agreement with Hor et al (1987). The XRD (figure 3) shows the presence of considerable impurity content in the sample along with the 1-2-3 phase. The (013) and (103) reflections are not distinctly separated. However the orthorhombicity was confirmed from the shouldered (200) reflection along with (020). The composition of the sample determined by oxygen estimation was found to be $\mathrm{LaBa}_{2} \mathrm{Cu}_{3} \mathrm{O}_{6 \cdot 8}$. The interesting feature is that only the nitrate-derived $\mathrm{La} \mathrm{1-2-3}$ gives values above liquid nitrogen $T_{c}$ values and observable orthorhombicity. It was found difficult to get rid off the impurities. Samples prepared at $850^{\circ} \mathrm{C}$ and $800^{\circ} \mathrm{C}$ show broad XRD reflections (figures 1 and 2). Though the (002) and (020) reflections are not separately seen in XRD, it is presumed to be orthorhomic from oxygen estimation and merger of broad X-ray reflections (020) and (200).

Table 1 summarizes the preparation conditions and characteristics of the samples prepared by ceramic and nitrate methods.

\section{Conclusion}

The method of preparation and calcination schedules seems to decide the site occupancy of $\mathrm{Ba}^{2+}$ and $\mathrm{La}^{3+}$ ions. In addition oxygen stoichiometry is also crucial for reproducible $T_{c}$ values. Thus the optimum $\delta$ value to achieve near $90 \mathrm{~K}$ superconductivity in $\mathrm{LBC}$ is experimentally found to be $0 \cdot 2$.

\section{Acknowledgement}

The authors are thankful to Mr M Rajendran and Mr P A Joy of Indian Institute of Science, Bangalore for fruitful discussions. Thanks are also due to Prof. G V Subba Rao, IIT, Madras for valuable suggestions. 


\section{References}

Cava R J, Van Dover R B, Batlogg B and Rietman E A 1987 Phys. Rev. Lett. 58408

Engler V M et al 1987 J. Am. Chem. Soc. 1092848

Ganguly $\mathrm{P}$ et al 1987 J. Phys. 28 L 321

Hor P H et al 1987 Phys. Rev. Lett. 581891

Kishio K et al 1987 Chem. Letts. 21429

Murphy D W et al 1987 Phys. Rev. Letts. 581888

Nagarajan V et al 1987 J. Phys. 28 L321

Rao C N R, Ganguly P, Raychaudri A K, Mohan Ram R A and Sreedhar K 1987 Nature (London) 326856

Sampathkumaran E V, Paulose P L, Grover A K, Nagarajan V and Dhar S K 1987 Curr. Sci. 56252

Subba Rao G V, Varadaraju U V and Radhakrishnan T S 1987 Phase Trans. 10181

Wu M K et al 1987 Phys. Rev. Lett. 58908 